\title{
Relation between Serology and Grow-Up Time in Atypically Localized Hydatic Cysts
}

\author{
Atipik Lokalizasyonlu Kist Hidatiklerde Büyüme Hızı ve Seroloji İlişkisi
}

\author{
Ahmet Okuş, Barış Sevinç, Serden Ay, Ömer Karahan, Mehmet Ali Eryılmaz, Cemil Er \\ Clinic of General Surgery, Konya Training and Research Hospital, Konya, Turkey
}

\begin{abstract}
Objective: Hydatic cyst is a parasitic disease caused by the larvae of Echinococcus granulosus. In the study, the aim is to evaluate the relation between serology and grow-up time in atypically localized cysts.

Methods: Retrospectively, all the patients with hydatic disease between December 2004 and May 2012 were screened from the hospital database. Hydatic cyst localization other than the liver and lungs were accepted as atypical localization.

Results: There were 325 patients with a diagnosis of hydatic disease. Most common localizations of the cysts were the liver (72.8\%) and lungs (21\%). Atypically localized cyst rate was $6.4 \%$ (n: 21). The most common atypical localization was the spleen (2.4\%). $80.9 \%$ of atypically localized cysts were primary cases. In 3 cases with primary intramuscular hydatic cyst and 2 cases with primary subcutaneous hydatic cysts, serology was negative.

Conclusion: The relation between the hydatid cyst and the host is the main factor in serological tests and grow-up time. In tissues with a weaker cellular immunity like muscle and subcutaneous tissue, serology tends to be negative and grow-up time to be faster. In atypically localized cysts, hematogenous dissemination cannot explain the pathogenesis fully. Therefore, lymphatic dissemination should be kept in mind. (Turkiye Parazitol Derg 2013; 37: 257-61)
\end{abstract}

Key Words: Hydatid disease, atypical, rare, localization

Received: 13.01.2013

Accepted: 20.10 .2013

ÖZET

Amaç: Hidatik hastalık, sıklıkla Echinococcus granulosus larvalarının sebep olduğu parazitik bir hastalıktır. Bu çalışmada hidatik kistin atipik lokalizasyonu ile seroloji ve kistin büyüme hızı arasındaki ilişkinin araştırılması amaçlanmıştır.

Yöntemler: Aralık 2004 ile Mayıs 2012 tarihleri arasında hastanemizde hidatik kist nedeni ile tedavi edilmiş olan tüm hastalar hastanemiz veri tabanından retrospektif olarak tarandı. Hidatik kistin karaciğer ve akciğer dışı yerleşimi atipik lokalizasyon olarak kabul edildi.

Bulgular: Bu tarihler arasında hastanemizde hidatik kist nedeni ile 325 hasta tedavi edilmiş idi. En yaygın yerleşim yerleri karaciğer (\%72,8) ve akciğerler (\%21) idi. Karaciğer ve akciğer dışı yerleşim (atipik lokalizasyonlu hidatik kist) ise \%6,4 ( $\mathrm{n=21}$ ) idi. Atipik lokalizasyonlu hidatik kist en sık dalakta $(\% 2,4)$ gözlenmiştir. Primer kas içi hidatik kist olan 3 olguda, primer subkutan hidatik kisti olan 2 olguda seroloji negatiftir. Sonuç: Hidatik kist ile konakçı savunma sistemi arasındaki ilişki seroloji pozitifliğini ve kist büyüme hızını belirleyen ana unsurdur. Hidatik kist kas dokusu, subkutan doku gibi hücresel immünitenin daha zayıf olduğu dokularda serolojinin negatif olması ve daha hızlı büyüme eğilimindedir. Atipik lokalizasyonlu hidatik kistler için hematojen yol patogenezi izah etmek için yetersiz olup, bu olgularda lenfatik yayılımda söz konusu olabilir. (Turkiye Parazitol Derg 2013; 37: 257-61)

Anahtar Sözcükler: Kist hidatik, atipik, nadir, yerleşim

Geliş Tarihi: 13.01.2013

Kabul Tarihi: 20.10 .2013

Address for Correspondence / Yazışma Adresi: Barış Sevinç, MD, Clinic of General Surgery, Konya Training and Research Hospital, Konya, Turkey. Phone: +90505 4880511 E-mail: drbarissevinc@gmail.com doi:10.5152/tpd.2013.3056 


\section{INTRODUCTION}

Echinococcosis (hydatidosis, hydatid disease) is a zoonosis caused by the larval (metacestode) stages of cestodes (flat worms) belonging to the genus Echinococcus and the Family Taeniidae. Humans are an accidental, intermediate host and become infected when they accidentally ingest eggs of the tapeworm. The eggs hatch in the duodenum, and the released oncosphere penetrates the mucosa and reaches a blood vessel. The bloodstream can carry the oncosphere to any part of the body, but it most frequently settles in the liver and lungs. Once settled, the parasite develops its larval stage, the hydatid cyst, the clinical presentation of E. granulosus. The cellular response of host tissue is an attempt to encase the parasite in fibrous tissue. A developing cyst usually survives, with a steady increase in size of about 1 to $1.5 \mathrm{~mm}$ in diameter per month, depending on the site and adjacent structures (1).

The aim of this study is to evaluate the relation of atypical localization of the cyst and serological markers and grow-up time.

\section{METHODS}

Between December 2004 and May 2012, all the patients administered to hospital with a diagnosis of hydatidcyst were screened from hospital records. Patient information and localization of the cysts were recorded. The number of cysts, treatment modality and complications were defined.

Liver and lungs were accepted as typical localizations. Any localization other than the liver and lung were accepted as atypical localizations. The cases with atypically localized cyst and liver and/or pulmonary cyst were accepted as secondary cysts. Also, the cases with previously treated liver and/or pulmonary hydatic cysts were accepted as secondary cases. Atypically localized hydatic cyst without existing or previously treated liver and/or pulmonary hydatid cysts were accepted as primary cases.

In cases with a doubt in the diagnosis, ecchinococcus indirect hemaglutination (IHA) test was used (Echinococcosis Fumouse, France). In cases with a definitive diagnosis, the test was not used. An IHA level 1/160 and above was accepted as positive. However, in some cases the diagnosis was made by pathological examination after surgery (Intramuscular and subcutaneous hydatic cysts).

Preoperative ultrasonography was used in all the patients. In the diagnosis, computed tomography and/or magnetic resonance imaging were used as advanced studies. Patients were staged according to Gharbi staging in ultrasonography.

According to hospital records, patients' duration of complaints, serological test results and the diameter of the cysts were recorded. In secondary cases, atypically localized cyst diameter was accepted as the cyst diameter. Treatment methods, mortality, morbidity and recurrences were also recorded.

The patients were called and checked by phone whether they had any complaints or recurrences.

All the patients used albendazole $(100 \mathrm{mg} / \mathrm{kg})$ for 3 months.
A literature search was done and atypically localized hydatic cysts were evaluated in terms of being primary or secondary, localization, duration of complaints, serological tests and cyst diameter.

\section{Statistical analysis}

In this study IBM SPSS Statistics version 20 was used. The data was given as mean \pm standard deviation.

\section{RESULTS}

In this period, there were 325 cases with hydatid disease. There were 211 (64.9\%) female and 114 (35.1\%) male patients. Their mean age was $41.3 \pm 19.1$

The most common localization of the hydatid cyst was the liver $(72.8 \%, n=236)$, followed by the lungs $(21 \%, n=68)$. The rate of atypically localized cysts was $6.4 \%(n=21)$. The distribution of hydatid cysts according to localization was given in Table 1.

Atypically localized cysts were mostly localized in the spleen (2.4\%) (2 secondary and 6 primary cases). In second place were 4 intraabdominal hydatid cysts (3 primary and 1 secondary cases). Other rare localizations were given in Table 1. Interestingly, $80.1 \%$ of the atypically localized cysts (17 in 21) were primary cases.

In 3 splenic cysts, IHA was used and 2 were negative.The IHA test was positive in 2 secondary hydatic cysts (intraabdominal+liver and intraabdominal+liver+subcutaneous). In 2 of 3 primary intramuscular cysts and 2 primary subcutaneous cysts, IHA was negative (Table 2).

In splenic hydatid cysts, 3 cases were treated by PAIR (puncture, aspiration, injection, and reaspiration). In one case splenectomy was performed due to intraoperative bleeding and the other 4 cases underwent partial cystectomy. In renal hydatid cysts, one was treated by PAIR (Gharbi stage 1) and the other by partial cystectomy (Gharbi stage 4). Pancreatic hydatid cyst and the cyst in psoas muscle were treated by PAIR. The other cysts (intraabdominal, intramuscular and subcutaneous) were totally removed (Table 2).

Table 1. Localization of the hydatid cysts

\begin{tabular}{|l|c|c|}
\hline Localization & $\mathbf{n}$ & $\%$ \\
\hline Liver & 236 & 72.8 \\
\hline Lung & 68 & 21.0 \\
\hline Spleen & 6 & 1.9 \\
\hline Spleen + Liver & 1 & 0.3 \\
\hline Spleen + Lung & 1 & 0.3 \\
\hline Intraabdominal & 3 & 0.9 \\
\hline Intraabdominal + Liver & 1 & 0.3 \\
\hline Intraabdominal + & 1 & 0.3 \\
\hline Subcutaneous + Liver & 3 & 0.3 \\
\hline Intramuscular (Rectus abdominis - \\
gluteus maximus - psoas) & 2 & 0.6 \\
\hline Kidney & 2 & 0.6 \\
\hline Subcutaneous & 1 & 0.3 \\
\hline Pancreas & 325 & 100 \\
\hline Total & & \\
\hline
\end{tabular}


In 2 cases, there were wound infections and they were treated conservatively. In one case, there was abscess formation in the cyst pouch and it was percutaneously drained. There was no mortality and recurrence in the follow up.

\section{DISCUSSION}

Hydatic disease is endemic in countries were husbandry is common, such as the Mediterranean, Middle Asia, South America, New Zealand and South Africa (2-4). Most commonly, the liver (70\%) and lungs (10-15\%) are affected. Other than these organs, it is very rare $(2,3)$. The rate of hydatid cyst of the peritoneal cavity is $10-16 \%$ and they are secondary to minimal rupture of liver cysts or implantation during previous surgery. Sixty one percent of them are seen with liver cysts and primary intraperitoneal hydatid cysts are very rare $(2,4)$. Furthermore, hydatid cysts can be seen in muscular tissue, soft tissue, kidneys, spleen, bone and rarely in the brain, thyroid, breast and pancreas. Atypically localized hydatid cysts can be primary or secondary (2-4). In this study, the rate of intraperitoneal hydatid cyst is very low and most of the cases are primary cases (75\%). All those data in the literature are from small series; therefore, the rates are very different.

Atypically localized hydatid cysts other than the peritoneal cavity are explained by the escape of the embryos from the liver and pulmonary filter mechanisms and dissemination by the systemic circulation. However, primary atypically localized cysts are diffi-

Table 2. Clinical details of atypically localized hydatid cysts cult to be explained by systemic dissemination. In our study, $80 \%$ of atypically localized cysts are primary cases. Therefore, lymphatic dissemination besides systemic dissemination may be an effective mechanism (5). Hydatid cyst after a bee sting also supports this mechanism (6).

Serological test are useful in diagnosis. They rely on the basis of specific antibodies in the patient's plasma. There are many serological tests; however the most commonly used is the indirect hemaglutination test. IHA is a very sensitive test and is positive in $80 \%$ of hepatic hydatid cysts. Yet, a negative result cannot rule out the diagnosis. IHA has a high negativity rate in tissues other than the liver (7). Especially, in most of the muscular and subcutaneous hydatid cysts it gives negative results and has no diagnostic value $(4,8)$. In the literature, there are studies giving $66 \%$ serological positivity rates in atypically localized hydatid cysts (9), but generally it has very limited diagnostic value, as in this study.

Negative serology and absence of a primary focus (liver and lung) in atypically localized hydatid cysts are interesting findings. Those findings show that the ethiopathogenesis of the disease has not been fully understood yet.

Hydatid cysts used to be known as slowly growing lesions. The yearly growth rate is reported as $1 \mathrm{~cm}$ in some reference books and $4-5 \mathrm{~cm}$ in some studies $(10,11)$. Recently, the growth rate is determined as much higher than it previously known (12). In the

\begin{tabular}{|c|c|c|c|c|c|}
\hline Localization & $\begin{array}{c}\text { Serology } \\
(\mathrm{IHA}>1 / 160)\end{array}$ & $\begin{array}{c}\text { Cyst } \\
\text { diameter }\end{array}$ & $\begin{array}{l}\text { Gharbi } \\
\text { stage }\end{array}$ & $\begin{array}{c}\text { Duration of } \\
\text { symptoms (month) }\end{array}$ & Treatment \\
\hline Spleen & Negative & $4 \times 4$ & 1 & 6 & PAIR \\
\hline Spleen & Negative & $3 \times 3$ & 2 & 12 & PAIR \\
\hline Spleen & Negative & $3 \times 2$ & 2 & 24 & Partial Cystectomy \\
\hline Spleen & None & $6 \times 5$ & 1 & 3 & PAIR \\
\hline Spleen & None & $4 \times 3$ & 1 & 6 & Partial Cystectomy \\
\hline Spleen & None & $4 \times 3$ & 1 & 6 & Partial Cystectomy \\
\hline Spleen + Liver & None & $3 \times 5$ & 3 & 6 & Splenectomy \\
\hline Spleen + Lung & None & $4 \times 5$ & 1 & 5 & Partial Cystectomy \\
\hline Intraabdominal + Liver & Positive & & & & Cystectomy \\
\hline Intraabdominal & None & $15 \times 10$ & 4 & 6 & Cystectomy \\
\hline Intraabdominal & None & $10 \times 10$ & 2 & 12 & Cystectomy \\
\hline Intraabdominal & None & $3 \times 1$ & 3 & 3 & Cystectomy \\
\hline Intramuscular (Rectus abdominis) & Negative & $5 \times 4$ & 2 & 12 & Cystectomy \\
\hline Intramuscular (Psoas) & Positive & $7 \times 8$ & 2 & 1 & PAIR \\
\hline Intramuscular (Gluteus maximus) & Negative & $3 \times 5$ & 3 & 8 & Cystectomy \\
\hline Intraabdominal + Subcutaneous + Liver & Positive & $20 \times 20$ & 3 & 1 & Cystectomy \\
\hline Kidney & None & $7 \times 8$ & 1 & 18 & PAIR \\
\hline Kidney & None & $10 \times 10$ & 4 & 24 & Partial Cystectomy \\
\hline Subcutaneous (Back) & Negative & $8 \times 10$ & 1 & 4 & Cystectomy \\
\hline Subcutaneous (Face) & Negative & $4 \times 3$ & 1 & 0,5 & Cystectomy \\
\hline Pancreas & Negative & $4 \times 3$ & 1 & 3 & PAIR \\
\hline
\end{tabular}


Table 3. Atypically localized hydatid cysts in the literature

\begin{tabular}{|c|c|c|c|c|c|}
\hline Author & $\begin{array}{l}\text { Primary/ } \\
\text { secondary }\end{array}$ & Localization & $\begin{array}{l}\text { Duration of } \\
\text { symptoms }\end{array}$ & Serology & $\begin{array}{l}\text { Cyst diameter } \\
(\mathrm{cm})\end{array}$ \\
\hline Kouskos E et al 2007 [13] & Primary & $\begin{array}{l}\text { Right thigh (between muscle and } \\
\text { subcutaneous tissue) }\end{array}$ & Recent years & Positive & $5 \times 10$ \\
\hline \multirow[t]{2}{*}{ Dirican A et al 2008 [14] } & Primary & thigh (subcutaneous) & 1 year & Negative & $8 \times 9$ \\
\hline & Primary & Palm (subcutaneous) & $?$ & Negative & $2 \times 3$ \\
\hline Bilgic S et al 2009 [15] & Primary & Paraspinal & 5 months & Negative & $5 \times 5$ \\
\hline Eryılmaz MA et al 2010 [16] & Primary & Right gluteal (intramuscular) & 2 months & Negative & $5 \times 3$ \\
\hline Şehitoğulları A et al 2006 [17] & Primary & Latissimus dorsi (intramuscular) & 6 months & $?$ & $10 \times 15$ \\
\hline \multirow[t]{3}{*}{ Demirel AH et al 2007 [18] } & Primary & Right trapezius muscle (intramuscular) & $?$ & Negative & $3 \times 3$ \\
\hline & Primary & Below clavicle (subcutaneous) & $?$ & Negative & $4 \times 5$ \\
\hline & Primary & Retroperitoneal & $?$ & Positive & $15 \times 15$ \\
\hline Battyany I et al 2011 [6] & Primary & $\begin{array}{l}\text { Right popliteal region } \\
\text { (subcutaneous) }\end{array}$ & $\begin{array}{l}\text { Lower than } \\
7 \text { days }\end{array}$ & $?$ & $3 \times 4$ \\
\hline Ölmez A et al 2010 [19] & Primary & Right lumbar region (subcutaneous) & $?$ & Positive & $4 \times 3$ \\
\hline Öcalan K et al 2011 [20] & Primary & Right thoracal region (subcutaneous) & $?$ & Negative & $15 \times 10$ \\
\hline Kurt A et al 2009 [4] & Primary & Left leg (intramuscular) & 2 years & Positive & $15 \times 8$ \\
\hline Ozsoy M et al 2011 [21] & Primary & Axillary region & 2 months & Negative & $3 \times 3$ \\
\hline Dirican A et al 2011 [22] & Primary & Lumbar region (intramuscular) & 2 months & Positive & $6 \times 5$ \\
\hline Masoodi Ml et al 2011 [23] & Primary & Pancreas & 6 months & Positive & $7 \times 6$ \\
\hline Avcu S et al 2010 [24] & Primary & Thyroid and submandibular glands & 2 years & Positive & $3 \times 2$ \\
\hline Bhat NA et al 2011 [25] & Primary & Pancreas & 4 months & Negative & $15 \times 7$ \\
\hline
\end{tabular}

literature, the growth rate of hydatid cysts can be as high as in our study (6). Especially in subcutaneous and intramuscular cysts, the duration of complaints can inform us about the growth rate.

As a result of the reaction between the hydatic cyst and the host, immune mechanisms try to limit the cyst. This cellular and humoral reaction causes the formation of the fibrinous pericyst. Moreover, as a result of the humoral defense mechanism, antibodies are formed. Serological evaluation of those antibodies can help us in diagnosis. The main detector of the growth rate is the relation between the cyst and the host (1). Being asymptomatic in the liver and lungs finding a relation between the duration of complaints and the growth rate is difficult. However, in subcutaneous tissue, duration of the symptoms can inform us about the growth rate of the cyst.

A high serological positivity in solid organs like the liver and lungs and negativity in tissues with weaker cellular immunity like muscle and subcutaneous tissue is exciting. Atypically localized hydatid cysts are very rare and are reported as case studies. In Table 3, serological results, duration of symptoms and cyst diameters of atypically localized hydatid cysts in the literature are presented. As the duration of the symptoms increases, the positivity rate of serology increases. Moreover, in cases with shorter duration, almost all are serologically negative. The results of this study are similar to the literature. Furthermore, the case with a $3 \times 4 \mathrm{~cm}$ subcutaneous cyst shows that the growth rate can be very high and probably it is proportional to the escape from the immune response of the host.

\section{CONCLUSION}

The relation between the cyst and the host is the main factor in determination of serological positivity and the growth rate. In subcutaneous and muscular tissue, hydatid cysts tend to grow faster and the serological tests tend to be negative. In atypically localized hydatid cysts; hematogenous dissemination is not sufficient to explain the pathogenesis, and lymphatic dissemination may play an important role. The main limitation of the study is that atypically localized hydatid cysts are very rare and all data about them are from small case series.

Conflict of Interest: No conflict of interest was declared by the authors.

Financial Disclosure: The authors declared that this study has received no financial support.

Peer-review: Externally peer-reviewed.

Ethics Committe Approval: Ethics committee approval was not received due to the retrospective nature of the study.

Informed Consent: Written informed consent was not obtained due to the retrospective nature of the study.

Author Contributions: Concept - A.O., B.S.; Design - A.O., B.S., Ö.K.; Supervision - Ö.K.; Funding - C.E., M.A.E., A.O.; Materials-C.E., M.A.E., A.O.; Data Collection and/or Processing 
- S.A., B.S., A.O.; Analysis and/or Interpretation - B.S., A.O.; Literature Review - A.O., Ö.K.; Writing - A.O., B.S.; Critical Review - M.A.E., S.A., C.E.

Acknowledgements: The authors thank Süleyman Bakdık, Kemal Arslan and Canan Sevinç for their contributions to the study.

Çıkar Çatışması: Yazarlar çıkar çatışması bildirmemişlerdir.

Finansal Destek: Yazarlar bu çalışma için finansal destek almadıklarını beyan etmişlerdir.

Hakem değerlendirmesi: Dış bağımsız.

Etik Komite Onayı: Çalışmanın retrospektif tasarımından dolayı etik kurul onayı alınmamıştır.

Hasta Onamı: Çalışmanın retrospektif tasarımından dolayı hasta onamı alınmamıştır.

Yazar Katkıları: Fikir - A.O., BS.; Tasarım - A.O., B.S., Ö.K.; Denetleme - Ö.K.; Kaynaklar - S.A., C.E.; Malzemeler - C.E., M.A.E., A.O.; Veri toplanması ve/veya işlemesi - S.A., B.S., A.O.; Analiz ve/veya yorum - B.S., A.O.; Literatür taraması - A.O., Ö.K.; Yazıyı yazan - A.O., B.S.; Eleştirel Inceleme - M.A.E., S.A., C.E.

Teşekkür: Yazarlar Süleyman Baktık, Kemal Arslan ve Canan Sevinç'e çalışmaya olan katkılarından dolayı teşekkür eder.

\section{REFERENCES}

1. Milicevic M, 2007. Echinococcal Cysts: Cause, Diagnosis, Complications, and Medical and Surgical Treatment. Mastery of Surgery, Fischer JE, $5^{\text {th }}$ Edition, Lippincott Williams \& Wilkins, p: 1044-7.

2. Prousalidis J, Tzardioglou K, Sgouradis L, Katsohis C, Aletras H. Uncommon sites of hydatid disease. World J Surg 1998; 22: 17-22. [CrossRef]

3. Kayaalp C. Hydatid cyst of the liver. In: Blumgart LH, Belghiti RJ, DeMatteo RP, Chapman WC, Büchler MW, Hann LE, D'Angleca M, editor. Surgery of the Liver, Biliary Tract, and Pancreas. 4. Philadelphia, PA: Saunders Elsevier; 2007. p. 952-70. [CrossRef]

4. Kurt A, Onuray F, Kurt B, Çulhadaroğlu AB, 2009. Primary intramuscular hydatic cyst: case report. Cumhuriyet Tıp Derg 2009; 31: 445-7.

5. Ok E, Sözüer EM. Solitary subcutaneous hydatid cyst: a case report. Am J Trop Med Hyg. 2000; 62: 583-4.

6. Battyany I, Andrea L, Nagy KK. Subcutaneous hydatid cyst in the popliteal fossa at the site of a previous wasp sting. Diagn Interv Radiol 2011; 17: 163-5.

7. Miman Ö, Atanbay M, Aydın NE, Daldal N. Clinical, morphological and serological Evaluation 91 cases operated due to cystic echinococcosis. Turkish journal of Parasitology 2010; 34: 179-83.
8. Dudkiewicz I, Salai M, Apter S. Hydatid cyst presenting as a softtissue thigh mass in a child. Arch Orthop Trauma Surg 1999; 119: 474-5. [CrossRef]

9. Gougoulias NE, Varitimidis SE, Bargiotas KA, Dovas TN, Karydakis G, Dailiana ZH. Skeletal muscle hydatid cysts presenting as soft tissue masses. Hippokratia 2010; 14: 126-30.

10. Von Lichtenberg F, 1991. Pathology of infectious diseases, Raven Press; New York. p. 331-5.

11. Gelen T, Elpek GÖ, Aktan S, Emek K. Hepatic unilocular cystic ecchinococcosis in Mediterranean region (73 cases). Turkish journal of Echopathology 1995; 1: 113-7.

12. Terblanche J, Krige JEJ. Liver Echinococcosis. In: Cameron JL, editor. Current Surgical Therapy, sixth edition, Philadelphia 2001; 324-9.

13. Kouskos E, Chatziantoniou J, Chrissafis I, Anitsakis C, Zamtrakis S. Uncommon locations of hydatid cysts. Singapore Med J 2007; 48: 119-21.

14. Dirican A, Unal B, Kayaalp C, Kirimlioglu V. Subcutaneous hydatid cysts occurring in the palm and the thigh: two case reports. J Med Case Rep 2008; 13: 273. [CrossRef]

15. Bilgic S, Kose O, Sehirlioglu A, Safaz I, Ozkan H. Primary paraspinal hydatid cyst treated with puncture, aspiration, injection and re-aspiration (PAIR) technique: a case report. Eur Spine J 2009; 2: 165-7. [CrossRef]

16. Eryılmaz MA, Eroğlu C, Karabağlı P, Çobankaya OE. Gluteal Hydatid Cyst: Case Report. Turkish J Med Sci 2010; 30: 1380-3. [CrossRef]

17. Şehitoğulları A, Atik B, Demir C. Primary localization of hydatic cyst in latissimus dorsi muscle. Tıp Araştırmaları Dergisi 2006; 4: 49-51.

18. Demirel AH, Akgün A, Öngören AU, Kısakürek M, Erol MF. Atypically localized hydatic cysts. Akdemik Gastroenteroloji Dergisi 2007; 6: $158-60$

19. Ölmez A, İtik V, Aydın C, Kayaalp C. Primary Subcutaneous Hydatid Cyst at the Flank: A Case Report. Eur J Surg Sci 2010; 1: 93-5.

20. Öcalan K, Köseoğlu C, Esme H, Solak O. Thoracal wall subcutaneously localized hydatic cyst: case report. Türk Göğüs Kalp Damar Cerrahisi Dergisi 2011; 19: 467-9.

21. Ozsoy M, Keles C, Kahya M, Keles G. Primary ecchinococcal cyst in the axillary region. J Infect Dev Ctries 2011; 5: 825-7. [CrossRef]

22. Dirican A, Sümer F, Ünal B, Barut B, Işık B, Yılmaz S, 2011. Two cases of primary intramuscular hydatid cyst in the same family. Dicle Med J 38 (4): 486-8. [CrossRef]

23. http://dx.doi.org/10.5798/diclemedj.0921.2011.04.0071. [CrossRef]

24. Masoodi MI, Nabi G, Kumar R, Lone MA, Khan BA, Naseer Al Sayari K. Hydatid cyst of the pancreas: a case report and brief review. Turk J Gastroenterol 2011; 22: 430-2.

25. Avcu S, Unal O, Kotan C, Oztürk M, Ozen O. Submandibular and thyroid gland involvement of hydatid cysts: a very rare association with percutaneous treatment. Diagn Interv Radiol 2010; 16: 251-4.

26. Bhat NA, Rashid KA, Wani I, Wani S, Syeed A. Hydatid cyst of the pancreas mimicking choledochal cyst. Ann Saudi Med 2011; 31: 536-8. [CrossRef] 